\title{
Noise Insulation Renovation of Rail Transit Existing On-Ground Lines
}

\author{
Lei $\mathrm{Liu}^{1}$, Kun $\mathrm{Yao}^{2 *}$, Liyan $\mathrm{Wu}^{1}$, Meng Zhang ${ }^{2}$ \\ ${ }^{1}$ Beijing Urban Construction Design \& Development Group Co., Limited, 100037 Beijing, China \\ ${ }^{2}$ Beijing Municipal Institute of Labour Protection, 100054 Beijing, China
}

\begin{abstract}
Taking the noise insulation renovation project of two existing on-ground lines in a city of China as an example, this article introduces a renovation scheme and noise test results before and after renovation in detail. Based on the noise test results pre-renovation, the decision has been made to adopt the scheme of adding fully-enclosed noise barriers for noise reduction. Aligning with the status quo and construction characteristics of the Project, a reasonable renovation design scheme and construction scheme have been selected through comparison, and effective construction protection measures have been taken. This article is significant referential literature for noise insulation renovation for existing rail transit on-ground lines.
\end{abstract}

\section{Project Background}

The noise effect from rail transit operation on the residents along the line is an important environmental factor restricting development across urban rail transit. Designing and implementing noise reduction measures, such as noise barrier are effective solutions for addressing this issue $e^{[1-7]}$. This article introduces design and renovation methods for noise reduction measures for onground lines of rail transit by taking typical sections of two existing rail transit on-ground lines in a city of China. While constructing these two existing on-ground rail transit lines of the city, noise control measures were taken that complemented the noise-sensitive buildings along the on-ground lines. However, with the increase in urban construction scale and the change of business types and industry conditions along the lines, complaints about noise pollution caused by rail transit operations have been frequently submitted in recent years, which required more noise control measures to be implemented in certain sections. To this end, three noise-sensitive areas on Rail Transit Lines A and B were tested, and noise barriers were designed in 2017.

The basic conditions of the two lines are as follows:

The total length of Rail Transit Line A is $27.7 \mathrm{~km}$, including $10.8 \mathrm{~km}$ of on-ground and viaduct sections. The viaduct section has adopted box girders, employing $6 \mathrm{~B}$ train marshalling with a maximum speed of $80 \mathrm{~km} / \mathrm{h}$. Construction officially began at the end of 2002 and started trial operations in 2007;

The total length of Rail Transit Line B is $40.9 \mathrm{~km}$, primary on-ground and viaduct sections. The viaduct section adopts box girders, employing 6B train marshalling with a maximum speed of $80 \mathrm{~km} / \mathrm{h}$. Construction began in 1999 and started operations in 2002.
The noise-sensitive areas along Line A are existing residential buildings around the viaduct sections, and the noise-sensitive areas along Line $\mathrm{B}$ include existing residential buildings around the viaduct section and those around the subgrade section.

\section{Noise Effect Before Renovation}

\subsection{Test Scheme}

Test schemes have been determined to the conditions of noise-sensitive areas and the on-ground lines.

The test covers two operational conditions: before and after the implementation of renovation measures.

Two types of equivalent continuous A-weighted sound pressure level data were collected from testing. The data for calculating the insertion loss from the noise barrier was tested three times, each time lasted for 30 minutes, and the data for evaluating environmental noise was tested once during the day and once at night for one hour each time.

The test objects were determined in light of the specific noise-sensitive areas and the on-ground line conditions, including the reference points of noise barrier and the measuring points of residential building in the sensitive areas.

The reference points of the noise barrier are used to monitor changes in sound sources and calculate insertion loss for noise barriers. Because the noise barrier is designed to be fully-enclosed, its reference points cannot be selected using the methods specified in existing standards. ${ }^{[8]}$ Therefore, the noise barrier reference points are determined to be set at the opening position on the top of the noise barrier according to the actual conditions, as shown in Fig. 1.

*Corresponding author:yk_kun@hotmail.com 


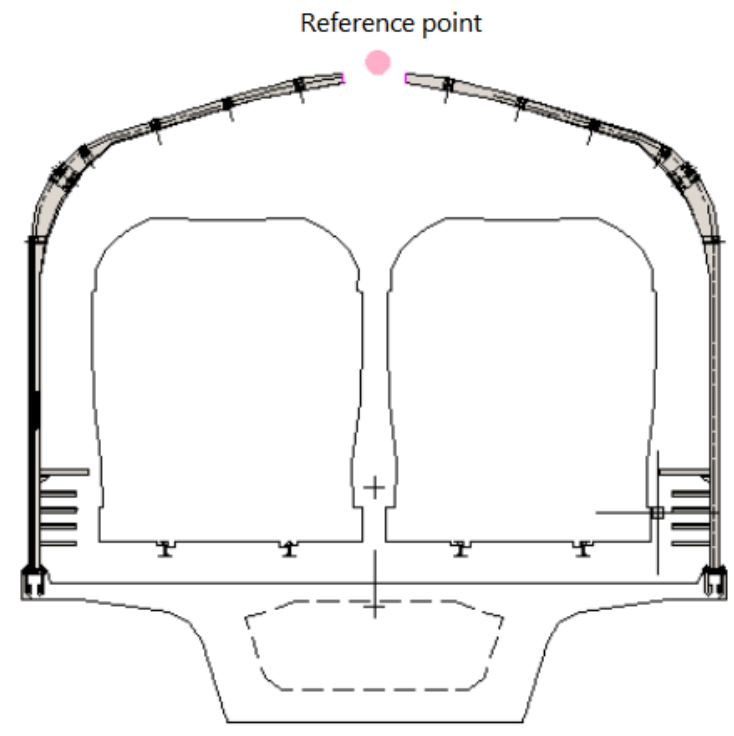

Fig.1. Status Quo of Viaduct - Section without Noise Barrier

The measuring points for residential buildings in sensitive areas are not only the sound receiving points in the calculation of noise barrier insertion losses, but also the environmental noise evaluation points of noisesensitive buildings. The layout is as follows:

One measuring point is allocated for the residential buildings near the viaduct section of Line A, at $1 \mathrm{~m}$ outside the window of the residential building, $15 \mathrm{~m}$ above the ground, and about $125 \mathrm{~m}$ from the center line of the near rail.

Two measuring points are allocated for residential buildings near the viaduct section of Line B. They are located at $1 \mathrm{~m}$ outside the window of the residential building at the $1 \mathrm{st}$ and $3 \mathrm{rd}$ floors respectively, about $38 \mathrm{~m}$ from the center line of the near rail.

Two measuring points are allocated for residential buildings near the subgrade section of Line B. They are located at $1 \mathrm{~m}$ outside the window of the residential building at the 1 st and 3rd floors respectively, about $38 \mathrm{~m}$ from the center line of the near rail.

The 2250 and 2270 Noise Acquisition Analyzers of B\&K and the INV3062T 4-channel data acquisition system of the China Orient Institute of Noise \& Vibration have been adopted.

\subsection{Test Results}

The test results of the above three areas are shown in Table 1 and Table 2.

Table 1. Test Results of Sound Receiving Points and Reference Points before the Implementation of Renovation Measures

\begin{tabular}{|c|c|c|c|c|}
\hline \multirow{2}{*}{$\begin{array}{c}\text { Measuri } \\
\text { ng Point }\end{array}$} & \multicolumn{2}{|c|}{$\begin{array}{c}\text { Sound Receiving } \\
\text { Points dB (a) }\end{array}$} & \multicolumn{2}{c|}{$\begin{array}{c}\text { Reference Points dB } \\
\text { (a) }\end{array}$} \\
\cline { 2 - 5 } Location & $\begin{array}{c}\text { Test } \\
\text { Sound } \\
\text { Pressu } \\
\text { re } \\
\text { Level }\end{array}$ & $\begin{array}{c}\text { Backgrou } \\
\text { nd Noise }\end{array}$ & $\begin{array}{c}\text { Sound } \\
\text { Pressu } \\
\text { re } \\
\text { Level }\end{array}$ & $\begin{array}{c}\text { Backgrou } \\
\text { nd Noise }\end{array}$ \\
\hline
\end{tabular}

\begin{tabular}{|c|c|c|c|c|}
\hline $\begin{array}{l}\text { Viaduct } \\
\text { Section } \\
\text { on Line } \\
\text { A }\end{array}$ & 59.1 & 56.4 & 75.9 & 74.6 \\
\hline \multirow{2}{*}{$\begin{array}{l}\text { Viaduct } \\
\text { Section } \\
\text { on Line } \\
\text { B }\end{array}$} & 64.6 & 54.0 & \multirow[b]{2}{*}{77.9} & \multirow[b]{2}{*}{56.6} \\
\hline & 62.7 & 51.2 & & \\
\hline \multirow{2}{*}{$\begin{array}{c}\text { Subgrade } \\
\text { Section } \\
\text { on Line } \\
\text { B }\end{array}$} & 66.9 & 58.9 & \multirow[b]{2}{*}{71.6} & \multirow[b]{2}{*}{62.5} \\
\hline & 63.1 & 57.8 & & \\
\hline
\end{tabular}

Table 2.Environmental Noise of Sensitive Points before the Implementation of Renovation Measures

\begin{tabular}{|c|c|c|c|c|}
\hline \multirow[b]{2}{*}{$\begin{array}{l}\text { Measuri } \\
\text { ng Point } \\
\text { Location }\end{array}$} & \multicolumn{2}{|c|}{ Daytime dB (A) } & \multicolumn{2}{|c|}{ Nighttime dB (A) } \\
\hline & $\begin{array}{c}\text { Test } \\
\text { Sound } \\
\text { Pressu } \\
\text { re } \\
\text { Level }\end{array}$ & $\begin{array}{c}\text { Backgrou } \\
\text { nd Noise }\end{array}$ & $\begin{array}{c}\text { Test } \\
\text { Sound } \\
\text { Pressu } \\
\text { re } \\
\text { Level }\end{array}$ & $\begin{array}{c}\text { Backgrou } \\
\text { nd Noise }\end{array}$ \\
\hline $\begin{array}{l}\text { Viaduct } \\
\text { Section } \\
\text { on Line } \\
\text { A }\end{array}$ & 57.9 & 55.4 & 58.6 & 56.8 \\
\hline \multirow{2}{*}{$\begin{array}{l}\text { Viaduct } \\
\text { Section } \\
\text { on Line } \\
\text { B } \\
\end{array}$} & 66.9 & 53.6 & 62.1 & 53.0 \\
\hline & 63.1 & 51.9 & 58.0 & 50.7 \\
\hline \multirow{2}{*}{$\begin{array}{c}\text { Subgrade } \\
\text { Section } \\
\text { on Line } \\
\text { B }\end{array}$} & 67.0 & 58.2 & 58.2 & 51.6 \\
\hline & 62.8 & 56.0 & 57.9 & 50.4 \\
\hline
\end{tabular}

The test results show that the environmental noise measured at the sensitive points in the viaduct section of Line $\mathrm{B}$ is significantly higher than background noise, indicating that the noise generated by rail transit operations significantly contributes to the environment. In light of the acoustic environment functional area where the measuring points are located and the corresponding acoustic environment quality standard limits[9], the standard limits in sensitive areas in the viaduct section of Line $\mathrm{A}$ are $55 \mathrm{~dB}$ (a) in the daytime, $45 \mathrm{~dB}$ (a) at night, and the other two places are $70 \mathrm{~dB}(\mathrm{a})$ in the daytime and $55 \mathrm{~dB}$ (a) at night, thus it can be seen that these three sensitive places are all over acceptable limits at night. The area in the viaduct section of Line $\mathrm{A}$ is over the limit in the daytime, and the main contributor is rail transit noise. To this end, it is a necessity to strengthen noise control measures in these three sensitive areas.

\section{Renovation Scheme}

\subsection{Design Scheme}

\subsubsection{Design Principles}

The implementation scheme for the renovation was designed based on noise test results. Because the background noise exceeded standard limits, the incremental value of rail transit noise should be controlled. Previous research literature have shown that ${ }^{[1-7]}$ the noise reduction effect from vertical noise barriers is $1 \sim 8 \mathrm{~dB}$, 
that of semi-enclosed noise barriers is $12 \mathrm{~dB}$, and that of fully-enclosed noise barriers is $20 \mathrm{~dB}$. In order to reduce impact on operations of existing rail transit lines, only noise barrier measures have been adopted for this sound insulation renovation, instead of implementing comprehensive shock absorption and noise reduction measures to the rail tracks and bridges, so the scheme of installing fully-enclosed noise barriers, which has the best noise reduction effect, was adopted. Due to the load limitation, the light screen material was adopted for renovation projects, which has a consistent form and appearance with the existing noise barrier of the line.

\subsubsection{Status Quo}

\section{(1) Existing Viaduct}

The existing viaduct is a double-track box girder with a width of 8.6-10 m, and some sections have vertical noise barriers, as shown in Fig. 2 and Fig. 3. On the side where the noise barrier is allocated, the noise barrier columns are also used as cable supports. The longitudinal spacing of the steel columns within a $2 \mathrm{~m}$ range at the lower end is $1 \mathrm{~m}$, and the longitudinal spacing of the columns or steel beams above $2 \mathrm{~m}$ is $2 \mathrm{~m}$. The sides without noise barriers are equipped with $1.4 \mathrm{~m}$ high balustrades, on which cable cover plates with handrails are allocated. The balustrades are made of 140 steel channels, with a longitudinal spacing of $1 \mathrm{~m}$, and the balustrades are also used as cable supports.

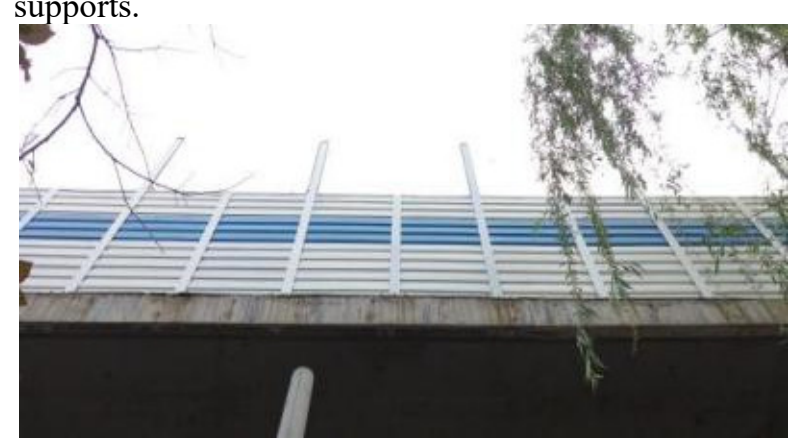

Fig. 2 .Status Quo of Viaduct - Section with Noise Barrier

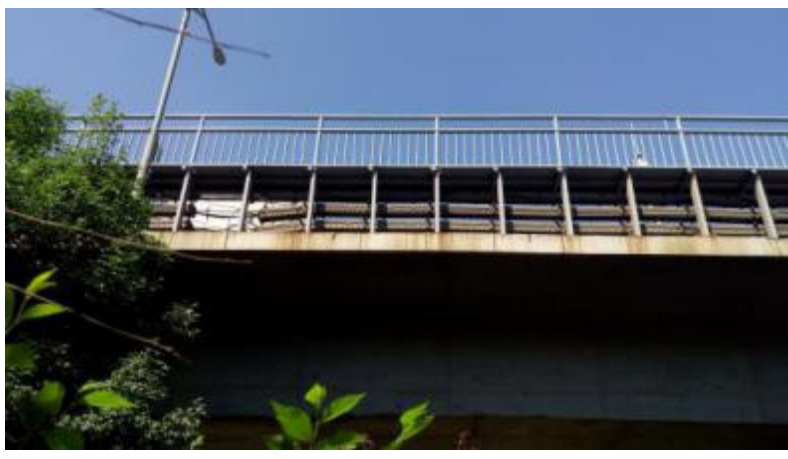

Fig. 3. Status Quo of Viaduct - Section without Noise Barrier

The noise barrier column base adopts a structural form with embedded bolts, which passes through embedded steel plates and the column base steel plates of the noise barrier to affix the columns of the noise barrier. The balustrade foundation adopts a structural form with castin fixing bolts, which are welded to the embedded steel plates without passing through them, and the balustrade columns are welded to the embedded steel plates.

(2) Subgrades of Existing Ground Lines

Existing ground lines are in subgrade form, and some sections have vertical noise barriers, as shown in Fig. 4 and Fig. 5. The retaining walls on both sides of the subgrade sections without noise barriers are allocated with $1.4 \mathrm{~m}$ high cable supports or blocking nets, and the spacing between cable posts is $0.8 \sim 1.5 \mathrm{~m}$. Cable cover plates with handrails are affixed to the cable supports. The cable supports are made of 140 steel channels with a longitudinal spacing of $1 \mathrm{~m}$.

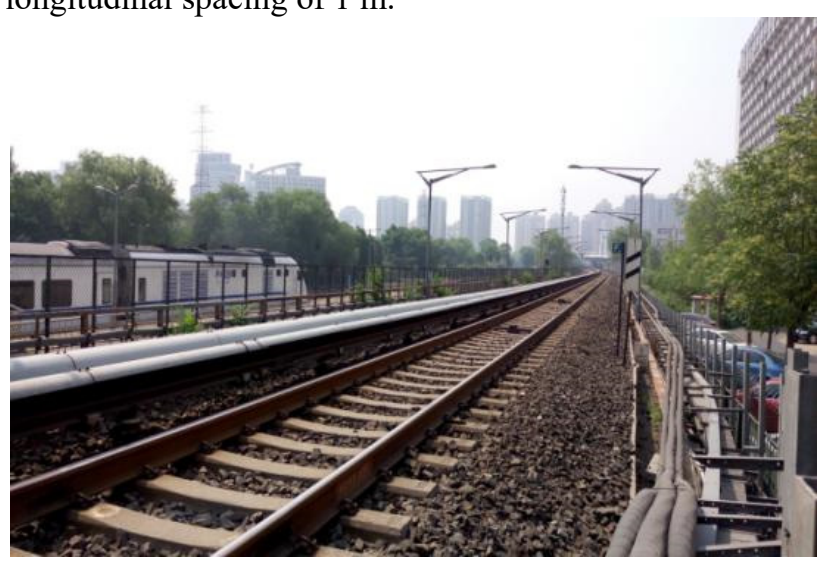

Fig. 4. Status Quo of Ground Subgrade

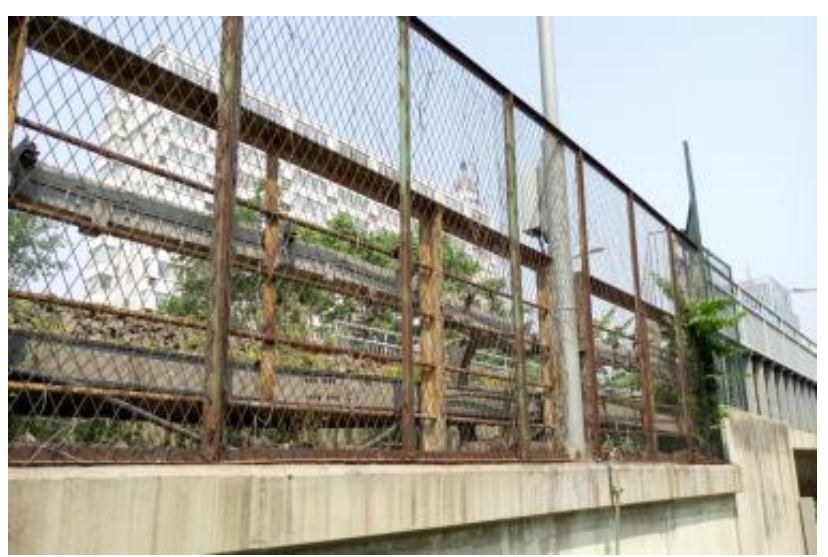

Fig. 5. Status Quo of Ground Subgrade - Blocking Net

The noise barrier column bases adopt a structural form with embedded bolts, which pass through the embedded steel plates and the column base steel plates of the noise barrier to affix the columns of the noise barrier. The foundation for cable supports and embedded parts are welded together.

\subsubsection{Design Scheme}

(1) Viaduct Design Scheme

The embedded sections at the sides of the existing vertical noise barriers are connected with bolts. After the steel plates on column bases are removed, the column bases are affixed by connecting the embedded parts with bolts. After verifying and calculating, it was found that the column bases on the balustrade side cannot be utilized. Therefore, a design for new perforations for planting steel bars has been adopted. The positions of newly planted 
steel bars should avoid steel plates of existing balustrade column bases. Dislocations, if any, can be corrected by adjusting the $\mathrm{H}$-shaped steel torsion angle.

Scheme 1: The longitudinal bridge spacing for portal steel frames of fully-enclosed noise barriers is designed as $2 \mathrm{~m}$, and the steel structure has adopted HW100x100x6x8. Because of the large stresses on the steel structure, Q355C steel is used. According to the construction procedure, operations on the bridge can be carried out in the forms of integral hoisting, sectional hoisting and assembly on the bridge, but for the sectional assembly construction method, the vertical load condition shall be considered in the calculation.

Scheme 2: The longitudinal bridge spacing for portal steel frames of fully-enclosed noise barriers is designed as $1 \mathrm{~m}$, employing HW100x100x6x8 steel structure and Q355C steel. If employing the hoisting method, priority is given to integral hoisting.

Table 3. Comparison of Noise Barrier Portal Frame Schemes

\begin{tabular}{|c|c|c|}
\hline Selected Steel & Scheme 1 & Scheme 2 \\
\hline $\begin{array}{c}\text { Consistency with } \\
\text { spacing for noise } \\
\text { barriers along the } \\
\text { full line }\end{array}$ & Consistent & Q235C \\
\hline $\begin{array}{c}\text { Impact on dead } \\
\text { loads of the } \\
\text { second phase }\end{array}$ & Small impact & Large impact \\
\hline $\begin{array}{c}\text { Column base } \\
\text { stress }\end{array}$ & $\begin{array}{c}\text { The reaction force } \\
\text { of column base is } \\
\text { large, but it meets } \\
\text { the requirements }\end{array}$ & $\begin{array}{c}\text { The reaction force } \\
\text { of column base is } \\
\text { small, but it meets } \\
\text { the requirements }\end{array}$ \\
\hline Cost Comparison & Low cost & High cost \\
\hline
\end{tabular}

From the above comparison, we can see that it is more reasonable to use a longitudinal spacing of $2 \mathrm{~m}$ for noise barrier frames, so Scheme 1 is recommended, as shown in Fig. 6 and Fig. 7.

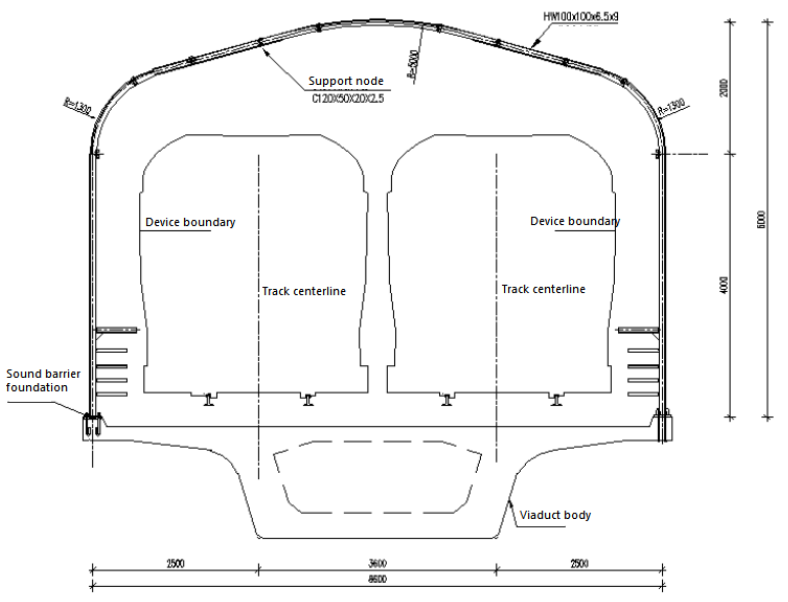

Fig. 6.Transverse Section of Noise Barrier Portal Frame in Scheme 1

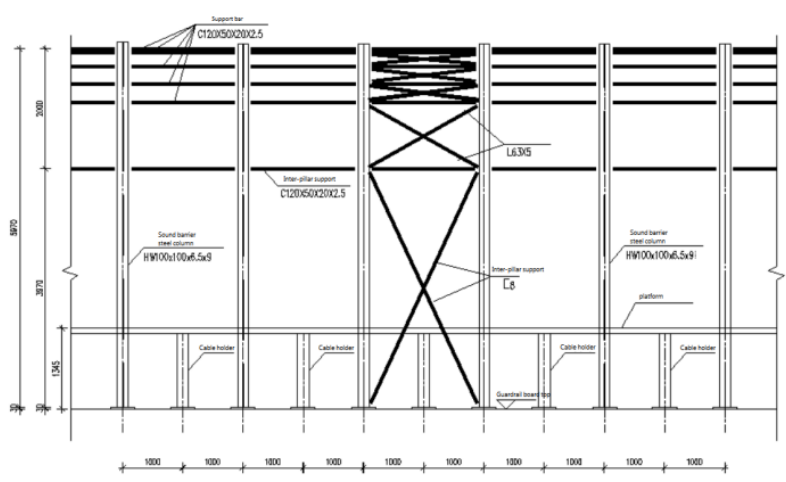

Fig. 7.Longitudinal Section of Noise Barrier Portal Frame in Scheme 1

In order to ensure normal operations of the power supply, the $\mathrm{H}$-shaped steel bars on the existing vertical noise barriers shall be removed at intervals, and shall be cut into $2 \mathrm{~m}$ high cable support columns. On the sides of existing balustrades, $2 \mathrm{~m}$ high cable support columns shall be built, and the interval between cable supports and noise barrier supports shall be $1 \mathrm{~m}$.

From the bottom to the top, the fully-enclosed noise barrier screen for viaducts is: sound absorption and insulation panels, vertical transparent sound proof windows, sound absorption and insulation panels, and top transparent sound proof windows. The top or upper parts of the fully-enclosed noise barrier sides are equipped with a ventilation and smoke exhaust vent, with an that satisfies the requirements for natural ventilation and smoke exhaust.

(2) Design Scheme for Ground Subgrades

The embedded parts on existing vertical noise barrier sides are connected with bolts. After the column base steel plates are removed, the column bases are affixed by connecting the embedded parts with bolts. After verifying and calculating, it was found that cable support column bases on the side without a noise barrier cannot be utilized. Therefore, a form of continuous beams supported on the new pile foundation has been adopted.

The fully-enclosed noise barrier in subgrade sections have adopted the portal steel frame with a longitudinal spacing of $2 \mathrm{~m}$, and beam-column joints are connected by high-strength bolts. The portal steel frames are hoisted in twice. The portal steel columns are hoisted first, and then the portal steel beams are installed. The pile foundation is adopted for the noise barrier foundation in subgrade sections, and the foundations are connected with continuous beams.

From the bottom to the top, the fully-enclosed noise barrier screens for subgrade sections are: sound absorption and insulation panels, vertical transparent sound proof windows, and top transparent sound proof windows. The top or upper parts on fully-enclosed noise barrier sides are provided with a ventilation and smoke exhaust vent, with an area that satisfies the requirements of natural ventilation and smoke exhaust. 


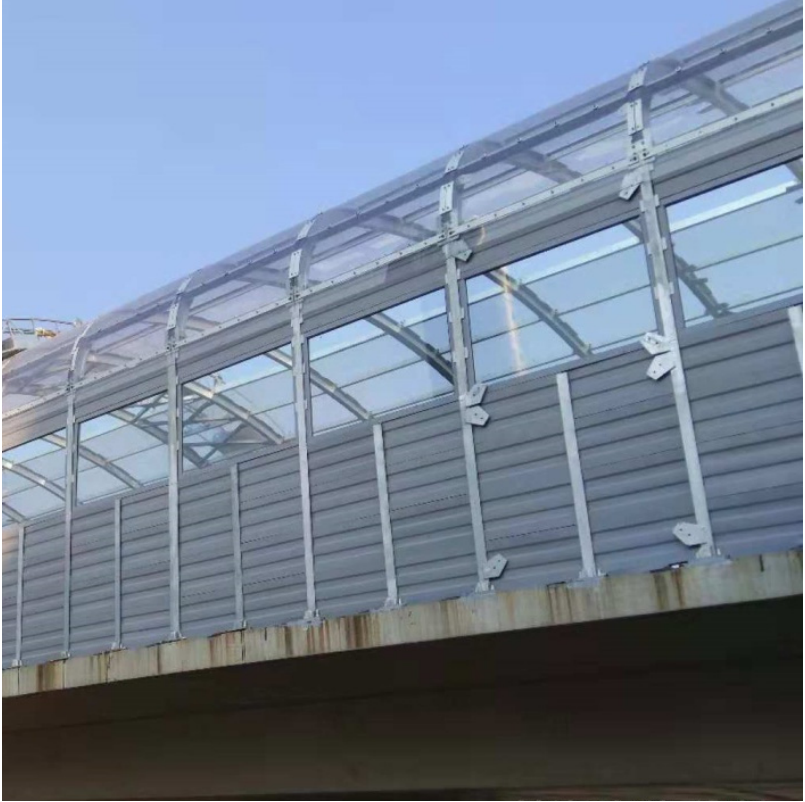

Fig. 8.Actual Picture of Viaduct Noise Barrier After Installation

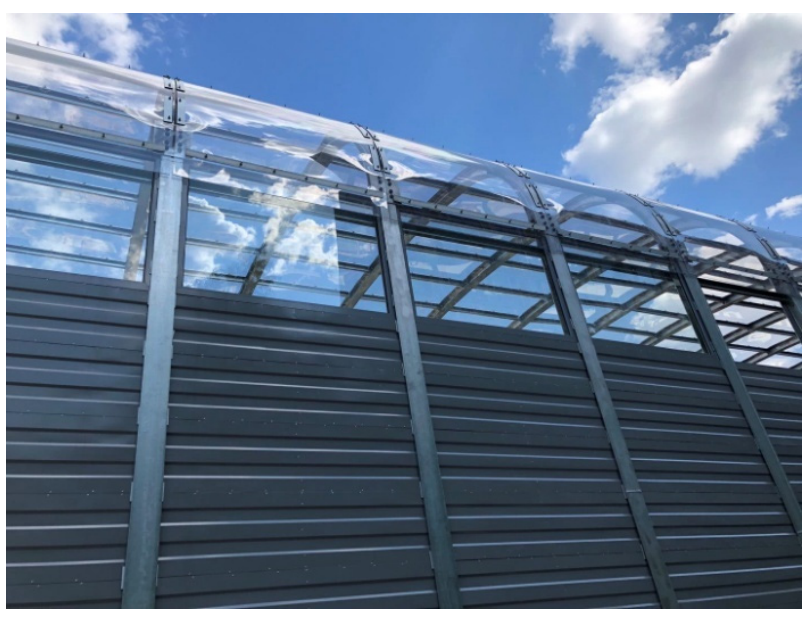

Fig. 9. Actual Picture of Ground Subgrade Noise Barrier After Installation

\subsection{Construction Scheme}

\subsubsection{Construction Procedure}

\section{(1) Viaduct Construction Procedure}

1) Side with Existing Noise Barrier

Dismantle the H-shaped steel, cable cover plates, and cable supports within the construction range $\rightarrow$ Grind the pre-embedded plates for anti-corrosion treatment $\rightarrow$ Assemble the portal steel frame columns and beams into an integral structure; install short columns and column bracing and longitudinal supports; install purlins $\rightarrow$ Restore and install cable cover plates and cable supports $\rightarrow$ Install the lower sound absorption and insulation panels, transparent sound proof windows, and the upper sound absorption and insulation panels $\rightarrow$ Install top transparent sound proof windows $\rightarrow$ Install street lamps.

2) Side with Existing Balustrades
Perforate and plant steel bars $\rightarrow$ Remove balustrades, street lamp posts, and cut openings into cable cover plates $\rightarrow$ Cut original steel channel columns; remove cable supports, cable cover plates and their longitudinal supports; install cable cover plate bracket connectors $\rightarrow$ Assemble the portal steel frame column and beam into an integral structure; install short columns and column bracings and longitudinal supports; install purlins; install cable supports (reuse) $\rightarrow$ Install the lower sound absorption and insulation panels, transparent sound proof windows, and the upper sound absorption and insulation panels $\rightarrow$ Dismantle street lamp posts $\rightarrow$ Install top transparent sound proof windows $\rightarrow$ Install street lamps.

(2) Construction Procedure for Ground Subgrades

1) Side with Existing Noise Barrier

Dismantle the H-shaped steel within the construction site $\rightarrow$ Grind the pre-embedded plates for anti-corrosion treatment $\rightarrow$ Assemble the portal steel frame columns and beams into an integral structure; install column bracings and longitudinal supports; install purlins $\rightarrow$ Install the lower sound absorption and insulation panels, transparent sound proof windows $\rightarrow$ Install top transparent sound proof windows $\rightarrow$ Install street lamps.

2) Side without Noise Barrier

Establish new crown beam bases for pile foundation $\rightarrow$ Dismantle street lamps $\rightarrow$ Assemble the portal steel frame columns and beams into an integral structure; install longitudinal supports; install purlins $\rightarrow$ Install the lower sound absorption and insulation panels, transparent sound proof windows $\rightarrow$ Install top transparent sound proof windows $\rightarrow$ Install street lamps.

\subsubsection{Safety Protection}

The construction site for this Project is on rail transit operational lines, where many pieces of professional equipment and facilities are distributed. Before demolition, therefore, effective safety precautions shall be carried out for both the equipment and facilities within the construction scope.

Because the construction site is located on the main line, it is necessary to protect the track, three-rail, professional equipment and facilities, as well as cable pipelines on the primary line during construction to ensure rail transit normal operations.
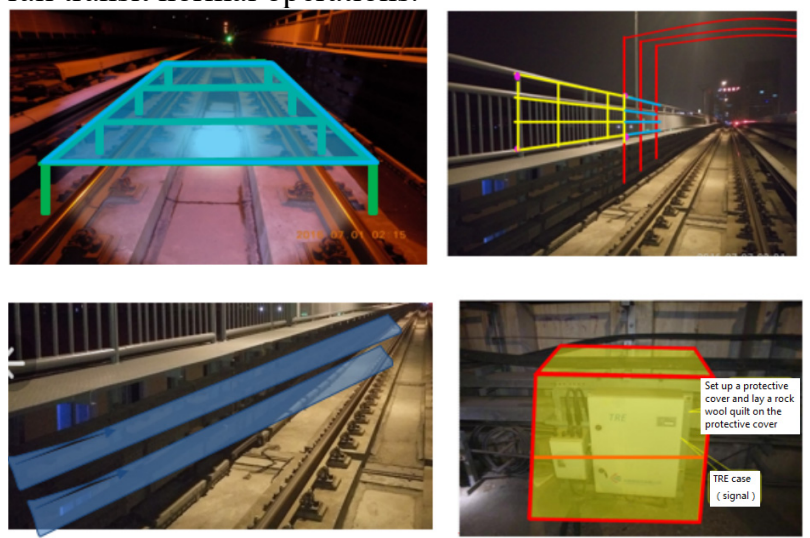

Fig. 10. Construction Safety Protection Scheme 


\section{Renovation Effect Analysis}

After implementing the noise reduction renovation project for the previous three sensitive areas of Rail Transit Lines $\mathrm{A}$ and $\mathrm{B}$, the same schemes were adopted again to perform the corresponding noise tests, and the test results are shown in Table 4 and Table 5.

Table 4. Test Results of Sound Receiving Points and Reference Points after Implementing Renovation Measures

\begin{tabular}{|c|c|c|c|c|}
\hline \multirow[b]{2}{*}{$\begin{array}{l}\text { Measuri } \\
\text { ng Point } \\
\text { Location }\end{array}$} & \multicolumn{2}{|c|}{$\begin{array}{l}\text { Sound Receiving } \\
\text { Points dB (a) }\end{array}$} & \multicolumn{2}{|c|}{$\begin{array}{l}\text { Reference Points dB } \\
\text { (a) }\end{array}$} \\
\hline & $\begin{array}{c}\text { Test } \\
\text { Sound } \\
\text { Pressu } \\
\text { re } \\
\text { Level }\end{array}$ & $\begin{array}{c}\text { Backgrou } \\
\text { nd Noise }\end{array}$ & $\begin{array}{c}\text { Test } \\
\text { Sound } \\
\text { Pressu } \\
\text { re } \\
\text { Level }\end{array}$ & $\begin{array}{c}\text { Backgrou } \\
\text { nd Noise }\end{array}$ \\
\hline $\begin{array}{c}\text { Viaduct } \\
\text { Section } \\
\text { on Line } \\
\text { A } \\
\end{array}$ & 51.7 & 49.4 & 75.3 & 55.3 \\
\hline \multirow{2}{*}{$\begin{array}{c}\text { Viaduct } \\
\text { Section } \\
\text { on Line } \\
\text { B }\end{array}$} & 60.4 & 55.2 & \multirow[b]{2}{*}{80.3} & \multirow[b]{2}{*}{56.2} \\
\hline & 59.2 & 56.8 & & \\
\hline \multirow{2}{*}{$\begin{array}{c}\text { Subgrade } \\
\text { Section } \\
\text { on Line } \\
\text { B }\end{array}$} & 61.5 & 60.5 & \multirow[b]{2}{*}{74.2} & \multirow[b]{2}{*}{66.2} \\
\hline & 60.3 & 59.7 & & \\
\hline
\end{tabular}

Table 5. Environmental Noise of Sensitive Points after Implementing Renovation Measures

\begin{tabular}{|c|c|c|c|c|}
\hline \multirow[b]{2}{*}{$\begin{array}{l}\text { Measuri } \\
\text { ng Point } \\
\text { Location }\end{array}$} & \multicolumn{2}{|c|}{ Daytime dB (A) } & \multicolumn{2}{|c|}{ Nighttime dB (A) } \\
\hline & $\begin{array}{c}\text { Test } \\
\text { Sound } \\
\text { Pressu } \\
\text { re } \\
\text { Level }\end{array}$ & $\begin{array}{l}\text { Backgrou } \\
\text { nd Noise }\end{array}$ & $\begin{array}{c}\text { Test } \\
\text { Sound } \\
\text { Pressu } \\
\text { re } \\
\text { Level }\end{array}$ & $\begin{array}{c}\text { Backgrou } \\
\text { nd Noise }\end{array}$ \\
\hline $\begin{array}{l}\text { Viaduct } \\
\text { Section } \\
\text { on Line } \\
\text { A }\end{array}$ & 48.0 & 47.8 & 49.3 & 48.8 \\
\hline \multirow{2}{*}{$\begin{array}{l}\text { Viaduct } \\
\text { Section } \\
\text { on Line } \\
\text { B }\end{array}$} & 60.2 & 55.6 & 57.3 & 56.8 \\
\hline & 59.9 & 56.0 & 57.0 & 56.6 \\
\hline \multirow{2}{*}{$\begin{array}{c}\text { Subgrade } \\
\text { Section } \\
\text { on Line } \\
\text { B } \\
\end{array}$} & 61.5 & 60.8 & 57.2 & 56.8 \\
\hline & 60.4 & 59.6 & 56.4 & 56.1 \\
\hline
\end{tabular}

Test results show that the difference between the test results from sensitive points and background results are significantly reduced after renovation, which indicates that the contribution of noise generated by rail transit operations to the environment has been greatly reduced. In line with the environmental noise standards ${ }^{[9]}$, after renovation, the noise in these three areas does not exceed standard limits during the daytime. Although it exceeds standard limits at night, the noise increment is less than $0.5 \mathrm{~dB}(\mathrm{~A})$.

Since the noise test results are close to the background noise after implementing the renovation measures, insertion loss analysis cannot be carried out as per standard requirements ${ }^{[9]}$. In consideration of the particularity and reality of the noise barrier, the energybased noise superposition theory is directly adopted to eliminate any influences the background noise has on the measured values, and the insertion loss of noise barriers at five sound receiving points is calculated and analyzed. The results are as follows:

Noise Barrier of Viaduct Section on Line A: $13.3 \mathrm{~dB}$

Noise Barrier of Viaduct Section on Line B: $8.6 \mathrm{~dB}$; $10.1 \mathrm{~dB}$

Noise Barrier of Subgrade Section on Line $13.4 \mathrm{~dB}$; $11.3 \mathrm{~dB}$

The analysis results show that the noise reduction effect from noise barriers at the previous three areas fundamentally satisfies the requirements, and the rail transit noise was effectively controlled.

\section{Conclusion}

Through field tests on noise-sensitive points, a reasonable noise control scheme has been determined. After implementing noise insulation renovation, field test results satisfy the requirements. A total length of 1,600 m fully-enclosed noise barriers has been installed to these two lines at a cost of RMB 74 million (about USD 10.5 million). In the noise barrier renovation scheme, the integral frame hoisting method has been adopted after considering the characteristics of construction at night. In the construction process, a variety of safety protection measures and actions have been taken to ensure normal operations. It is very difficult to install fully-enclosed noise barriers on existing lines of rail transit without halting operation, rarely used in previous renovation projects. Implementing this Project has significantly improved the acoustic environment for surrounding residents, and also provides experiences and reference for similar projects to some extent.

\section{References}

1. Zhu Lipeng and Ma Shenyi, "Brief Introduction to the Design of Noise Barrier for Viaduct Rail Transit" [J]. Underground Engineering and Tunnel, 2005, (2): 14-16, 25

2. Lei Bin. Research and Design of Noise Barrier of Wuhan Rail Transit[J]. Urban Rapid Rail Transit, 2007, 20 (1): 97-100.

3. Li Xiaozhen, Yang Dewang, Zheng Jing, et al. "Research Progress in Vibration and Noise Reduction of Rail Transit Bridges" [J]. China Journal of Highway and Transport, 2018, 31 (7): 55-71.

4. Yang Dewang, "Study on Noise Reduction Effect of Fully-Enclosed Noise Barrier for High-Speed Railway Bridge" [D]. Chengdu: Southwest Jiaotong University, 2018.

5. Tang Jian, "Study on Prediction of Vibration and Noise of U-Beam Bridge Structure and Influence of Key Parameters of Urban Rail Transit" [D]. Chengdu: Southwest Jiaotong University, 2018.

6. Li Xiaozhen, Yang Dewang, Gao Wei, et al., 
"Study on Vibration and Noise Reduction Effect of Semi-Enclosed and Fully-Enclosed Noise Barriers for High-Speed Railway [J]. Noise and Vibration Control, 2018, Z1:8-13.

7. Ma Na, "Engineering Design of Fully-Enclosed Noise Barrier for Shanghai Rail Transit Line 6" [J]. Modern Urban Rail Transit, 2010, (5): 38-39.

8. State Environmental Protection Administration. HJ/T 90-2004 "Norm on Acoustical Design and Measurement of Noise Barriers" [S]. Beijing: China Environmental Science Press, 2004.

9. Ministry of Environmental Protection, General Administration of Quality Supervision, Inspection and Quarantine of the People's Republic of China. GB 3096-2008 Environmental Quality Standard for Noise [S]. Beijing: China Environmental Science Press, 2008. 